Logos Universality Mentality Education Novelty, Section: LAW

ISSN: $2284-5968$ (print), ISSN: $2284-5968$

(electronic)

Covered in: CEEOL, Index Copernicus, Ideas

$\mathrm{RePeC}$, EconPapers, Socionet

COUNCIL REGULATION (EC) NO 2201/2003 MECHANISM OF MODERNISATION FOR NATIONAL LEGISLATIONS IN THE FIELD OF FAMILY RELATIONSHIPS

Roxana Gabriela ALBĂSTROIU

Logos Universality Mentality Education Novelty, Section:

LAW, 2014, Year III, Issue 1, pp: 11-20

Published by:

Lumen Publishing House

On behalf of:

Lumen Research Center in Social and Humanistic Sciences 


\title{
Council Regulation (EC) No 2201/2003 - Mechanism of Modernisation for National Legislations in the Field of Family Relationships
}

\author{
Roxana Gabriela ALBĂSTROIU1
}

\begin{abstract}
The European Union has turned its sights to family law. Brussels now tells us where we can raise proceedings in family cases. The European Union has brought together in a single legal instrument the provisions on divorce and parental responsibility, with a view to facilitating the work of judges and legal practitioners and to regulating the exercise of crossborder rights of access. This regulation represents a major step forward in the fight against violation of the right to privacy and family life. It establishes a full system of rules on jurisdiction. Many European states still have a limited regulation of the reasons for getting the dissolution of marriage. The European Convention (regulate the right to family and private life and, respectively, the right to marriage in art. 8 and 12 ECHR) bas nothing to do with such cases because does not regulates the right to divorce and it would be an interference into the national law. In this paper we intend to find out what changes bring the regulation into national legislation and that raises many questions: How can a person be married again if be/she doesn't have the possibility to divorce? In these conditions, can we take the European Convention into consideration as a real instrument of protection for the right to marriage? What the regulation means and what are the legal effects which it produces its application in the Member State legislation?
\end{abstract}

Keywords:

Council regulation, ECHR, divorce, legal separation, family life.

1 Associate Assistant, PhD, Faculty of Law and Social Sciences, Law specialization, University of Craiova, Romania, E-mail: roxana_albastroiu@yahoo.com, Phone: 0040751146551. 


\section{Introduction}

The Council Regulation (EC) no. 2201/2003 concerning jurisdiction and the recognition and enforcement of judgments which came into force on 1 August 2004 and applies from 1 March 2005 in matrimonial matters and the matters of parental responsibility. It is also known as Brussels II bis, which superseded the Council Regulation (EC) no. 1347/2000 applied to matrimonial matters and some children's cases and known as "Brussels II" (Of 29 May 2000 - came into force on 1 March 2001).

Brussels II bis is a European Union Regulation on conflict of law issues in family law between member states; in particular those related to divorce, child custody and international child abduction. It is applicable in all EU Member States except Denmark (http://ec.europa.eu/justice_en.htm).

How the first text of this regulation says the European Community has set the objective of creating an area of freedom, security and justice, in which the free movement of persons is ensured. To this end, the Community is to adopt, among others, measures in the field of judicial cooperation in civil matters that are necessary for the proper functioning of the internal market. The purpose of this Act is to create a genuine judicial area, so The Tampere European Council endorsed the principle of mutual recognition of judicial decisions. We can say that it is a piece of European legislation which defines which country will have jurisdiction to deal with a divorce.

In this paper we propose to analyze issues relating to dissolution of marriage which are covered in this regulation. In this way we can see the evolution of legislation in family law field in European Union and how it has influenced the modernization of legislation in our country.

\section{The scope of the Regulation no. $2201 / 2003$}

Generally, the scope of this Regulation covers civil matters, whatever the nature of the court or tribunal. As regards judgments on divorce, legal separation or marriage annulment, this Regulation should apply only to the dissolution of matrimonial ties and should not deal with issues such as the grounds for divorce, property consequences of the marriage or any other ancillary measures.

The Brussels II Regulation points out which Member State has jurisdiction over legal requests for a divorce, legal separation or a marriage annulment. This only applies insofar the request intents to break the matrimonial link itself. The Brussels II Regulation also regulates the recognition of judgments which have established a divorce, legal separation or a marriage annulment in other Member States. It, however, has no meaning for the 
enforcement of such judgments in other Member States, because it is only applicable to proceedings relating to the marriage link as such, i.e. divorce, legal separation and marriage annulment. Despite the fact that these subjects may be interrelated to other matrimonial matters, such as property consequences of a marriage (division of community property), maintenance obligations (alimony on behalf of the former spouse or the children) or other possible accessory measures (the right to a name, etc.), the Brussels II Regulation does not affect these issues at all (http://www.europeancivillaw.com/brusselstwo2003.htm).

No other European Regulation or Convention has answers the question which matrimonial law is applicable to a marriage. Although as from 1 March 2006 a new Chapter is inserted into the Brussels II Regulation which covers this subject, it is not yet in force at this moment. The new Chapter IIA is introduced to harmonize conflict-of-law rules in matters of divorce and legal separation, based in the first place on the choice of the spouses. There are no other Conventions that point out which national law applies to a marriage.

Anyhow, the Regulation no. 2201/2003 does not deal with issues as the ground for a divorce, the fault of the spouses, the formal procedure to end the marriage and so on. Only after the court with jurisdiction has ended the marriage in accordance with the applicable national law of its State or of another country, the Regulation may show up again. A possible consequence of a divorce, legal separation or marriage annulment is the need to adjust registration at public records, like those of the registrar's office, or at the Tax Authorities. This requires that the registrar's office or Tax Authorities recognize the judgment of the courts of another Member State which has ended the marriage. That's why the Brussels II Regulation also arranges how judgments of the court of a Member State, which have established a divorce, legal separation or marriage annulment, are to be recognized by other Member States(http://www.europeancivillaw.com/brusselstwo2003.htm).

\section{Jurisdiction}

In matters relating to divorce, legal separation or marriage annulment, jurisdiction shall lie with the courts of the Member State (art. 3 Regulation)

- the spouses are habitually resident, or

- the spouses were last habitually resident, insofar as one of them still resides there, or

- the respondent is habitually resident, or

- in the event of a joint application, either of the spouses is habitually resident, or

- the applicant is habitually resident if he or she resided there for at least a year immediately before the application was made, or 


\section{Logos Universality Mentality Education Novelty}

Section: Law

- the applicant is habitually resident if he or she resided there for at least six months immediately before the application was made and is either a national of the Member State in question or, in the case of the United Kingdom and Ireland, has his or her "domicile" there.

In addition to these criteria, there are two others applicable in exceptional cases, based on the forum actoris in conjunction with other conditions. Consequently, the following are also accepted:

- jurisdiction may lie with the courts of the Member State in which the applicant is habitually resident if he or she resided there for at least a year;

- jurisdiction enjoyed by the courts of the Member State in which the applicant is habitually resident if he or she resided there for at least six months immediately before the application was made, provided that that State is the State of nationality. (COM/99/0220 - CNS 99/0110 / Official Journal C 247 E, 1999).

So, two subsidiary rules are applicable in some states. Article 4 confers jurisdiction for a "counterclaim" in respect of matters covered by the Regulation. Article 5 gives jurisdiction for conversion of judicial separation into divorce, in states where such a conversion is possible. A court of a Member State that has given a judgment on a legal separation shall also have jurisdiction for converting that judgment into a divorce, if the law of that Member State so provides.

There can be no prorogation of jurisdiction in matters of divorce. A state either has jurisdiction, or it does not have jurisdiction. If the court does not have jurisdiction it is bound to declare of its own motion that this is the case (art. 17). A person who is habitually resident in the EU, or is domiciled in the United Kingdom or Ireland, or a national of another member state cannot be sued for divorce, save in accordance with the Regulation (art. 6).

Where no court of a Member State has jurisdiction pursuant to articles that we have already discussed, the art. 7 of Regulation tell us that the jurisdiction shall be determined, in each Member State, by the laws of that State. As against a respondent who is not habitually resident and is not either a national of a Member State or, in the case of the United Kingdom and Ireland, does not have his "domicile" within the territory of one of the latter Member States, any national of a Member State who is habitually resident within the territory of another Member State may, like the nationals of that State, avail himself of the rules of jurisdiction applicable in that State.

Taking into account the grounds of jurisdiction laid down in Articles 3 to 5 of the Brussels II Regulation, Article 7, par. 1, BR II sets the boundary between grounds of an exclusive nature established by the Regulation and the principle of applying internal rules of jurisdiction, thus demonstrating the 
geographical limits of the Regulation. The requirements set out in Article 7, paragraph 2, BR II must be examined in the following sense (http://www.europeancivillaw.com/brusselstwo2003.htm):

- the applicant must be a national of a Member State habitually resident in another Member State. Hence the principle of assimilation between citizens of Member States for the purposes of Article 7, par. 1, BR II;

- the respondent must meet two conditions: on the one hand he or she must be habitually resident outside the Member States; on the other hand, he or she must not be a national of a Member State or have his or her "domicile" in a Member State (declaration provided for in Article 3, paragraph 2, BR II). Both conditions are concurrent; otherwise the situation would be one requiring application of one of the grounds in Article 3 BR II (Borras, 1998, C 221/44).

The United Kingdom is a member state with different legal systems applying in different "territorial units". Article 66 of the Regulation provides that a reference to habitual residence, or domicile, in a particular member state relates to residence or domicile in the territorial unit in question. The application in this way of the Regulation has been criticized in some reviews: "the treaty base for the Regulation, allows measures to be "necessary for the proper functioning of the internal market". It is arguable that the EU have exceeded their powers" (Scott, 2005: 355).

\section{Terminological issues in determining jurisdiction}

"Habitual residence" is a key concept in Brussels II bis and it is not defined. At first view, habitual residence is a question of fact. It has been said to mean residence which is being enjoyed for the time being and with the settled intention that it should continue for some time (Dickson v Dickson, 1990, SCLR 692). At one time it was thought that in order to be habitual, residence should be voluntary, but the Inner House has indicated that residence need not be voluntary to the habitual (Cameron v Cameron 1996 SCLR 25).

It was also thought that the residence should be lawful, in this case being necessary to prove with a rental agreement (Volza v Borreggine, 2014). The European Court of Justice in Swaddling v Adjudication Officer [1999] 2 FLR 184 (Murphy, Jh., 2005: 122) considered that habitual residence referred to the state in which persons habitually resided and where the habitual centre of their interests was to be found (Scott, 2005: 357).

For the purpose of this Regulation, "domicile" shall have the same meaning as it has under the legal systems of the United Kingdom and Ireland (art. 3 p. 2 Regulation). An adult could acquire a domicile of choice by the 
combination and coincidence of residence in a country and an intention to make his home in that country permanently or indefinitely.

Brussels II bis applies the concept of domicile in relation to the United Kingdom and Ireland. Other EU countries use "nationality" in place of domicile, so, for example an action could be raised in Italy if both spouses were Italian nationals, regardless of their domicile. These grounds are all founded on the principle that there must be a genuine connection between the involving person(s) and the Member State with jurisdiction. This connection can be that both spouses, or at least one of them, live or previously have lived in a particular Member State, or that both spouses have the nationality of that Member State.

\section{The proceeding}

Concerning the court referral procedure the art. 16 of regulation provides that a court shall be deemed to be seized:

(a) at the time when the document instituting the proceedings or an equivalent document is lodged with the court, provided that the applicant has not subsequently failed to take the steps he was required to take to have service effected on the respondent;

(b) if the document has to be served before being lodged with the court, at the time when it is received by the authority responsible for service, provided that the applicant has not subsequently failed to take the steps he was required to take to have the document lodged with the court. Where a court of a Member State is seized of a case over which it has no jurisdiction under this Regulation and over which a court of another Member State has jurisdiction by virtue of this Regulation, it shall declare of its own motion that it has no jurisdiction (art. 17).

Where a respondent habitually resident in a State other than the Member State where the action was brought does not enter an appearance, the court with jurisdiction shall stay the proceedings so long as it is not shown that the respondent has been able to receive the document instituting the proceedings or an equivalent document in sufficient time to enable him to arrange for his defence, or that all necessary steps have been taken to this end. Article 19 of Regulation (EC) No 1348/2000 shall apply instead of the provisions of paragraph 1 of this Article if the document instituting the proceedings or an equivalent document had to be transmitted from one Member State to another pursuant to that Regulation (Ghita, 2012: 29).

Where the provisions of Regulation (EC) No 1348/2000 are not applicable, Article 15 of the Hague Convention of 15 November 1965 on the service abroad of judicial and extrajudicial documents in civil or commercial 
matters shall apply if the document instituting the proceedings or an equivalent document had to be transmitted abroad pursuant to that Convention.

\section{Conflicts of jurisdiction}

Article 19 of Brussels II bis provides: Where proceedings relating to divorce, legal separation or marriage annulment between the same parties are brought before courts of different Member States, the court second sensed shall of its own motion stay its proceedings until such time as the jurisdiction of the court first sensed is established.

Where proceedings relating to parental responsibility relating to the same child and involving the same cause of action are brought before courts of different Member States, the court second sensed shall of its own motion stay its proceedings until such time as the jurisdiction of the court first sensed is established. Where the jurisdiction of the court first sensed is established, the court second sensed shall decline jurisdiction in favour of that court. In that case, the party who brought the relevant action before the court second sensed may bring that action before the court first sensed.

In urgent cases, the provisions of this Regulation shall not prevent the courts of a Member State from taking such provisional, including protective, measures in respect of persons or assets in that State as may be available under the law of that Member State, even if, under this Regulation, the court of another Member State has jurisdiction as to the substance of the matter. The measures referred to in paragraph 1 shall cease to apply when the court of the Member State having jurisdiction under this Regulation as to the substance of the matter has taken the measures it considers appropriate.

So article 20 allows a court to take provisional, including protective, measures in respect of persons or assets, even where the courts of another member state have jurisdiction as to the substance. This may not be broadly construed.

In Wermuth v Wermuth [2003] 1 WLR 94210.3 .6 a divorce action was commenced in Germany (Hill Jh., 2005). Before the German court had considered whether it was first sensed, the wife applied to the English court for maintenance pending suit (equivalent of interim aliment), and was awarded $f_{150,000}$ pa. (http://www.echr.coe.int/pages/home.aspx?p=caselaw). The German court did in fact assume jurisdiction and the husband appealed the English order. His appeal was allowed. The Court of Appeal held that the order to pay a sum for an indefinite period was an unwarranted invasion of the proper function of the German judge, who was the judge first sensed (Scott, 2005: 360). 


\section{Recognition of a judgment}

A judgment given in a Member State shall be recognized in the other Member States without any special procedure being required. In particular, and without prejudice to paragraph 3 , no special procedure shall be required for updating the civil-status records of a Member State on the basis of a judgment relating to divorce, legal separation or marriage annulment given in another Member State, and against which no further appeal lies under the law of that Member State.

Without prejudice to Section 4 of this Chapter, any interested party may, in accordance with the procedures provided for in Section 2 of this Chapter, apply for a decision that the judgment be or not be recognized. The local jurisdiction of the court appearing in the list notified by each Member State to the Commission pursuant to Article 68 shall be determined by the internal law of the Member State in which proceedings for recognition or nonrecognition are brought. Where the recognition of a judgment is raised as an incidental question in a court of a Member State, that court may determine that issue (article 21).

A judgment relating to a divorce, legal separation or marriage annulment shall not be recognized:

a) if such recognition is manifestly contrary to the public policy of the Member State in which recognition is sought;

b) where it was given in default of appearance, if the respondent was not served with the document which instituted the proceedings or with an equivalent document in sufficient time and in such a way as to enable the respondent to arrange for his or her defence unless it is determined that the respondent has accepted the judgment unequivocally;

c) if it is irreconcilable with a judgment given in proceedings between the same parties in the Member State in which recognition is sought;

d) if it is irreconcilable with an earlier judgment given in another Member State or in a non-Member State between the same parties, provided that the earlier judgment fulfils the conditions necessary for its recognition in the Member State in which recognition is sought.

The article 25 of Regulation provides that the recognition of a judgment may not be refused because the law of the Member State in which such recognition is sought would not allow divorce, legal separation or marriage annulment on the same facts. The competent court or authority of a Member State of origin shall, at the request of any interested party, issue a certificate using the standard form. 


\section{Conclusion}

The application of the Regulation no. 2201/2003 in the EU Member States is a step in the unification of family relations legislation. Being part of the applicant states Romania knows another element of modernity. The courts in our country already have in their jurisdiction divorce cases were the parties are European citizens, citizens of EU Member States. We proposed in this paper to debate the regulation text evoking different opinions or bringing into question various causes.

\section{Acknowledgment:}

This work was supported by the strategic grant POSDRU/159/1.5/S/141699, Project ID 141699 co-financed by the European Social Fund within the Sectorial Operational Program Human Resources Development 2007-2013.

\section{REFERENCES}

Borras, A. (1998). Explenatory Report on the Convention, drawn up on the basis of Article K.3 of the Treaty on European Union, on Jurisdiction and the Recognition and Enforcement of Judgments in Matrimonial Matters (approved by the Council on 28 May 1998), Barcelona (98/C 221/04)

Civil Sentence no. 4788 in 1 April 2014, Jud. Cv., Voltra v Borreggine.

Civil Sentence no. 6592 in 8 May 2014, Jud. Cv., Spilotros v Rizæi.

Dashwood, Al., Iillion, Ch., Spencer, Jh., Ward A. (2001). Cambridge Yearbook of European Legal Studies. Hart Publishing, Cameron v Cameron 1996 SCLR 25, p. 389.

Ghiță, O. (2012). Les relations de famille dans l'Union Europeenne. EUE Publishing, p. 29.

Hill, Jh. (2005). International Commercial Disputes in English Courts, 3rd edition, Hart Publishing, North America, Wermuth v Wermuth [2003] 1 WLR 942, 10.3.6

http://ec.europa.eu/justice en.htm

http://www.echr.coe.int/pages/home.aspx?p=caselaw http://www.europeancivillaw.com/brusselstwo2003.htm

Murphy, Jh. (2005). International Dimensions in Family Law. Manchester University Press, Swaddling v Adjudication Officer [1999] 2 FLR 184, p. 122.

Scott, J. M. (2005). Resolving The Problems Of Jurisdiction In Family Law - Brussels II And Points West. Conference organised by CLT Scotland Edinburgh, pp. 
353-387,

http://www.murraystable.com/newsarticles/articles/resolving-the-problems-of-jurisdiction.

Stone, P. (2010). EU Private International Law. Edward Elgar Publishing, Dickson v Dickson, 1990, SCLR 692, p. 432. the Field of Family Relationships. Logos Universality Mentality Education Novelty, Section: LAW, Year III, Issue 1, 2014, pp. 